\title{
The Management ToOls AND Methods APPlication OF the Organization to Environmental Protection
}

\author{
Miroslav Rusko, Ruzena Kralikova \& Monika Mikulova
}
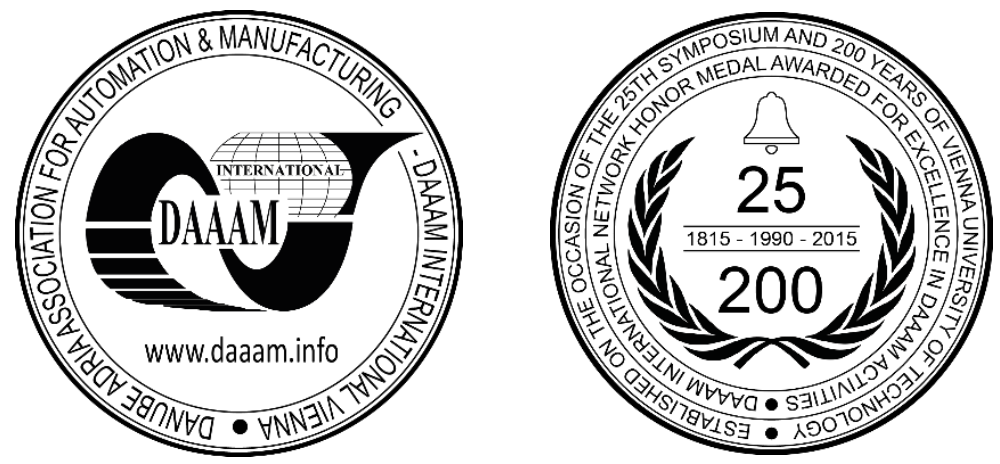

This Publication has to be referred as: Rusko, M[iroslav]; Kralikova, R[uzena] \& Mikulova, M[onika] (2016). The Management Tools and Methods Application of the Organization to Environmental Protection, Proceedings of the 27th DAAAM International Symposium, pp.0283-0288, B. Katalinic (Ed.), Published by DAAAM International, ISBN 9783-902734-08-2, ISSN 1726-9679, Vienna, Austria DOI: $10.2507 / 27$ th.daaam.proceedings.042

\begin{abstract}
This paper describes the approaches development of organizations to environmental protection through several stages from complete passivity, over so-called the reactive approach to the proactive principles. The passive approach relies on the power of nature to dispose of waste by own assimilative capacity, the reactive approach is based on a strategy of control and management especially in relation to the legislative measures and the proactive principle, applied in developed countries since the nineties of the twentieth century is based on the fact of prevention of pollution occurrence being cheaper and more effective than to subsequently remove it, or bear the consequences. A proactive approach focuses on eliminating problems before they have a chance to appear and a reactive approach is based on responding to events after they have happened. The difference between these two approaches is the perspective each one provides in assessing influences and their impacts. The aim of environmentally oriented management based on the proactive principles is use the special management tools and methods application are the subject of this contribution.
\end{abstract}

Keywords: environment; management; protection; organisation; policy.

\section{Introduction}

Approach of organizations to environmental protection issues is important because it determines the strategy of environmental protection that will be implemented into action at an organization.

Enterprises in the past responded to a variety of environmental challenges. First they did not respond at all, then respond only when a crisis occurs, and eventually integrating environmental management started into overall enterprise management through defined environmental management system in order to ensure sustainable development of society. It is a gradual transition from egocentric approach, allowing for the fact that nature will deal with any activity, towards the eco-centric one, which takes into account environmental considerations in economic activities of the company [5].

For the business enterprise, sustainable development means adopting business strategies and activities that meet the needs of the enterprise and its stakeholders today while protecting, sustaining and enhancing the human and natural resources that will be needed in the future. If sustainable development is to achieve its potential, it must be integrated into the planning and measurement and management systems of business enterprises [1]. Considering the rising costs of natural resources, the promulgation of environmental enforcement, new ways of thinking, patterns of future liability 
(e.g. Polluter Pays) and the increasingly competitive commercial market, it is indisputable that the application of voluntary tools in industry is a "win-win" situation, where production costs are reduced, energy is conserved, waste and emissions are reduced and relationships with stakeholders strengthened through increased transparency [10].

This paper considers the potential role for voluntary initiatives and environmental regulations in the transition toward more sustainable industrial systems. Several pervasive problems have hindered evaluation of their environmental effectiveness so far including poorly specified objectives, inadequate data on results and poorly specified baselines for comparison. Economic results indicate that in different circumstances, voluntary approaches may increase or decrease economic efficiency [8]. These considerations suggest that while voluntary initiatives can help us move toward more sustainable industrial systems, considerable advances in the design and analysis of voluntary initiatives will be required to harness their full potential.

\section{Modern pro-environmental oriented management approaches}

Modern pro-environmental oriented management approaches (as of BS 7750 standards, EMS, EMAS etc.) emphasizes the principle of continuous improvement, based on the Deming Cycle, Fig.1 [11].

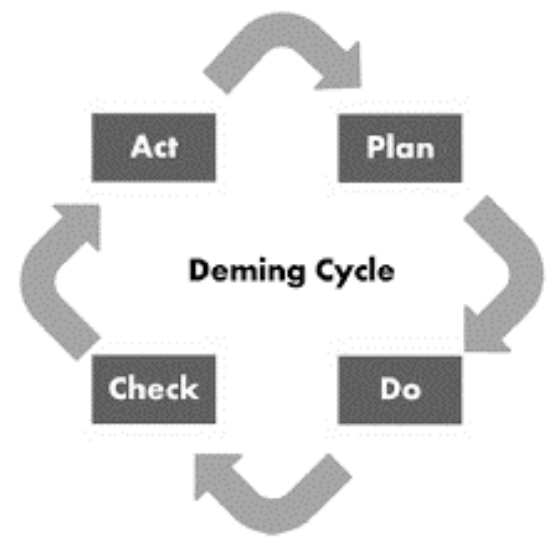

Figure 1. Deming cycle

The aim of environmentally oriented management is to minimize negative impacts on the environment, optimize the use of raw materials and energy resources, minimize waste and create conditions for sustainable development. Sustainable development is of an upmost priority of global society. We are talking of synchronized platform for:

- Integration, activity leaning towards sustainable development, monitoring and assessment.

- Support of domestic technological development, research in innovations including the need of suitable political environment for the development and besides other also industrial diversification.

- Modernization of infrastructure and renovation of industry in order to make them sustainable.

- Higher effectivity use of resources and better acceptance of clean and environmentally sound technologies and industrial processes.

- Achieving sustainable management and effective use of natural resources.

An important role has played and continues to play a shift in the threshold of general public and professional audience on the issue of environmental pollution. Based on consumer pressure there has been a shift towards proenvironmental activities in research, production and management organizations. This was followed by informing the consumer sector of such development e.g. the environmentally-friendly products [2]. Followed by received feedback, which is consumers have become a driving force, for those who make decisions on the market:

- Primary, which product is acceptable for them in terms of environmental protection,

- Secondary, purchasing environmentally sound products (or making provision for the purchase of a product weather the producer has implemented EMS (EMAS), decide which organization is successful in the market.

Such an important role can be successfully proven for consumers who are pro-environmentally oriented and environmental protection is at their value-among the priorities. In terms of implementation of environmental policy in practice it is not a priority to persuade once convinced, but to provide an appropriate form of information (such as environmental labeling type I) to persuade undecided, respectively consumerist-oriented consumers to become proenvironmentally oriented driving force in the market [3], [4].

Because an organization with an established EMS requires that subcontractors gradually introduce EMS and so gradually widened the application of voluntary environmental policy instruments. Although it is voluntary system, organization with an established EMS prefer subcontractors and partner organizations with established EMS. This creates pressure on the corporate sector, should an organization want to succeed in the market, it has to "voluntarily" implement EMS. Organization is not forced by legislation and sanction based environmental policy instruments, but is voluntarily moved into pro-environmental oriented path where the results often go beyond the measures of legislative and penalty mechanisms of the state. A similar approach and orientation can be seen with environmental product 
labelling type I. This way, we find a gradual solution to tackle a serious environmental problems and their elimination. The relevant threshold shift of an organization is applied in addition to the environmental sensitivity and moment of competition and selection. Competition among organizations to achieve success, also due to their pro-environmental orientation within its own economic policies are the driving force of the market. Thus such oriented organizations in selection of their partners in the context of their business prefer organizations that are similarly pro-environmentally oriented respectively they tolerate to a certain time (given impulse), while partner organization (subcontractor) starts in its economic activities to implement optional pro-environmental tools. In this way, more and more organizations involved in voluntary pro-environmental oriented activities.

\begin{tabular}{|l|l|l|l|}
\hline & \multicolumn{3}{|c|}{ Type of behavior } \\
\hline $\begin{array}{l}\text { Intensity of organization } \\
\text { involvement }\end{array}$ & $\begin{array}{l}\text { Social and environmental } \\
\text { duty }\end{array}$ & $\begin{array}{l}\text { Social and environmental } \\
\text { response }\end{array}$ & $\begin{array}{l}\text { Social and environmental } \\
\text { sensitivity }\end{array}$ \\
\hline Emphasis on: & $\begin{array}{l}\text { Economic and } \\
\text { environmental legislative } \\
\text { responsibility of an } \\
\text { organization }\end{array}$ & $\begin{array}{l}\text { Economic and } \\
\text { environmental legislative } \\
\text { responsibility of an } \\
\text { organization }\end{array}$ & $\begin{array}{l}\text { Economic, environmental, } \\
\text { legislative, social and } \\
\text { public responsibility of an } \\
\text { organization }\end{array}$ \\
\hline
\end{tabular}

Table 1. Subject behaviour within the its own environmental responsibility

\begin{tabular}{|c|c|c|c|c|}
\hline \multicolumn{5}{|c|}{ OACHES OF AN ORGANIZATION TOWARDS ENV] } \\
\hline \multicolumn{2}{|c|}{$\begin{array}{l}\text { Passive approach } \\
\quad \Delta\end{array}$} & \multicolumn{3}{|c|}{$\begin{array}{l}\text { The organization practically does not care about the issue of environmental protection. (Note: } \\
\text { the state organizations may be constrained towards pro-environmental oriented activities e.g. } \\
\text { the availability of funds from a central source, respectively disinterest of competent bodies) }\end{array}$} \\
\hline \multicolumn{2}{|c|}{$\begin{array}{c}\nabla \\
\text { Reactive approach }\end{array}$} & \multicolumn{3}{|c|}{$\begin{array}{l}\text { - Organization responds to the development of environmental legislation. } \\
\text { Organization addresses issues of environmental protection solely on the ground to bring it } \\
\text { into line with regulatory measures (legislative and sanctions) however itself it does not } \\
\text { proactively seeks ways to minimize their negative effects on the environment. }\end{array}$} \\
\hline \multirow{2}{*}{\multicolumn{2}{|c|}{$\nabla$}} & \multicolumn{3}{|c|}{ Based on principles } \\
\hline & & Prev & & Integ \\
\hline \multirow{4}{*}{ 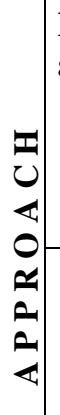 } & $\begin{array}{l}\text { Preventive } \\
\text { approach }\end{array}$ & $\begin{array}{l}\text { Prevention of pollution of the } \\
\text { environment (it is cheaper } \\
\text { and more effective than } \\
\text { additionally remove it, resp. } \\
\text { bears its consequences). }\end{array}$ & $\begin{array}{l}\text { Prevention of secondary } \\
\text { unwanted objects, i.e. not } \\
\text { only dangerous and toxic } \\
\text { products }\end{array}$ & $\begin{array}{l}\text { Complex evaluation process, ie } \\
\text { the process in question is } \\
\text { considered integrally in all stages } \\
\text { and effects of all environmental } \\
\text { impacts that are considered } \\
\text { inseparable }\end{array}$ \\
\hline & \multirow[t]{2}{*}{$\boldsymbol{\nabla}$} & \multicolumn{3}{|c|}{$\begin{array}{l}\text { inseparable } \\
\text { One-sided commitments as environmental polluters }\end{array}$} \\
\hline & & \multirow[b]{3}{*}{$\begin{array}{l}\text { Organization itself is actively } \\
\text { seeking ways in which the } \\
\text { impact of its activities on the } \\
\text { environment can be reduced }\end{array}$} & \multicolumn{2}{|c|}{$\begin{array}{l}\text { Public voluntary programs, i.e. voluntary environmental } \\
\text { solutions initiated by public institutions }\end{array}$} \\
\hline & \multirow[b]{2}{*}{$\begin{array}{l}\text { Voluntary } \\
\text { proactive } \\
\text { approach }\end{array}$} & & \multicolumn{2}{|c|}{$\begin{array}{l}\text { Negotiated agreements, i.e. voluntary environmental } \\
\text { agreements }\end{array}$} \\
\hline 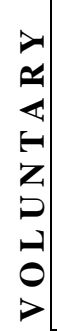 & & & \multicolumn{2}{|c|}{$\begin{array}{l}\text { The organization builds environmentally oriented management } \\
\text { approach (EMS/EMAS, resp. IMS) at all levels of organization } \\
\text { management. } \\
\text { This is based on the principles of continuous improvement, in } \\
\text { terms of own active environmental policy, with possible } \\
\text { application of additional / other environmental oriented tools. } \\
\text { The aim is to be constantly improving the environmental } \\
\text { efficiency and environmental performance of an organization. }\end{array}$} \\
\hline & $\begin{array}{l}\nabla \\
\text { Voluntary } \\
\text { proactive and } \\
\text { sustainable } \\
\text { management } \\
\text { approach }\end{array}$ & $\begin{array}{l}\text { Organization itself is actively } \\
\text { seeking ways to align its } \\
\text { activities with sustainable } \\
\text { development }\end{array}$ & \multicolumn{2}{|c|}{$\begin{array}{l}\text { Organization builds environmentally oriented management } \\
\text { approach at all levels of management, which is based on the } \\
\text { principles of continuous improvement, in terms of its active } \\
\text { environmental policy. } \\
\text { Using EST is improving environmental efficiency and } \\
\text { environmental performance of an organization in accordance } \\
\text { with the paradigm of sustainability. }\end{array}$} \\
\hline
\end{tabular}

Explanatory note: $\boldsymbol{\Delta} \boldsymbol{\nabla}$ - no strict boundaries exist between individual approaches, transition stages of development.

Table 2. Systemization of basic approaches of and organization towards environmental protection.

The result should be that organizations, which proactively address the potential, respectively existing environmental problems, reduce the negative impact of their business on the environment [9]. The measures implemented by the 
company in the context of environmental management can have a diverse nature - from minor organizational measures to technical and technological changes that require major investments. In its ultimately lead to more efficient use of resources, environmentally respectful processes, reduced-emission and impacts etc. [5].

The organization must realize that environmental responsibility lies within themselves. It is not enough to rely solely on meeting the standards set by the legislative-sanction instruments of state policies and thus transfer the responsibility of the environment to the state [6]. Types of subject (organization) behavior as part of own environmental responsibility can be viewed in Table. 1. Systemization of organization approach towards environmental protection is possible from several viewpoints are list in Table 2 .

The voluntary instruments include activities (methods, procedures, patterns of behavior etc.), which are enumerated or standardized at the international level and which are implemented by businesses on voluntary basis, outside the scope of legislation [4]. The examples of management tools and methods application within the organization towards different approaches to environmental protection are showed on Table 3.

\begin{tabular}{|c|c|c|c|}
\hline \multicolumn{4}{|c|}{ MANAGEMENT TOOLS AND METHODS APPLICATION } \\
\hline \multicolumn{2}{|c|}{$\begin{array}{l}\text { Passive } \\
\text { approach }\end{array}$} & \multicolumn{2}{|c|}{$\begin{array}{l}\text { - From historical point } \\
\text { - Currently it is more issue of legislation breach and ignorance of legislative regulations }\end{array}$} \\
\hline \multicolumn{2}{|c|}{$\begin{array}{l}\text { Reactive } \\
\text { approach }\end{array}$} & \multicolumn{2}{|c|}{$\begin{array}{l}\text { - Dilution of pollutants prior their discharges into the environment } \\
\text { - End technologies (,end of pipe“ technology), i.e. capture of pollutants before they enter the } \\
\text { environment } \\
\text { - Concentration control of pollutants prior their release into the environment } \\
\text { - Execution of the so-called No Waste (low-waste) technology } \\
\text { - Recycling technologies }\end{array}$} \\
\hline \multirow{4}{*}{ 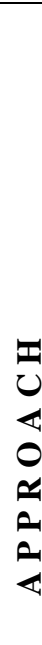 } & $\begin{array}{l}\text { Preventive } \\
\text { approach }\end{array}$ & $\begin{array}{l}\text { - Various forms of cleaner strategies } \\
\text { - Waste Reduction } \\
\text { - Waste Minimization } \\
\text { - Waste Reduction at the Source } \\
\text { - Reducing Pollution at the Source } \\
\text { - Pollution Prevention } \\
\text { - Eco-efficiency }\end{array}$ & f production - Cleaner Production \\
\hline & \multirow{4}{*}{$\begin{array}{l}\text { Voluntary } \\
\text { proactive } \\
\text { approach }\end{array}$} & $\begin{array}{l}\text { One-sided commitments as } \\
\text { environmental of polluters }\end{array}$ & - Program Responsible Care \\
\hline & & $\begin{array}{l}\text { Public voluntary programs, i.e. } \\
\text { voluntary environmental solutions } \\
\text { initiated by public institutions }\end{array}$ & $\begin{array}{l}\text { - EMAS (Eco-Management and Audit Scheme); } \\
\text { within EÚ } \\
\text { - Environmental evaluation and labelling of products, } \\
\text { national and multinational programs }\end{array}$ \\
\hline & & $\begin{array}{l}\text { Negotiated agreements, i.e. voluntary } \\
\text { environmental agreements }\end{array}$ & $\begin{array}{l}\text { - Conventions (,,covenants “) } \\
\text { - Individual public environ. agreements } \\
\text { - Private environ. agreements }\end{array}$ \\
\hline 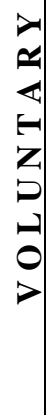 & & $\begin{array}{l}\text { The organization builds environ- } \\
\text { mentally oriented management: } \\
\text { EMS/EMAS, IMS. } \\
\text { Continuous improvement in terms of } \\
\text { own active environmental policy, with } \\
\text { application of additional/other } \\
\text { environmental oriented tools. } \\
\text { Improving the environmental } \\
\text { efficiency and environmental } \\
\text { performance of an organization. }\end{array}$ & $\begin{array}{l}\text { - EMS (Environmental Management Systems) } \\
\text { - EMAS (Eco-Management and Audit Scheme) } \\
\text { - EA - Environmental Audit } \\
\text { - ER - Environmental Reporting } \\
\text { - Environmental evaluation and labelling of products: } \\
\text { EL - Eco-labelling } \\
\text { - LCA - Life Cycle Assessment; Eco-balance } \\
\text { - Eco-design } \\
\text { - EPE - Environmental Performance Evaluation }\end{array}$ \\
\hline & $\begin{array}{l}\text { Voluntary } \\
\text { proactive and } \\
\text { sustainable } \\
\text { management } \\
\text { approach }\end{array}$ & \multicolumn{2}{|c|}{$\begin{array}{l}\text { Environmental tool mix based on application of generic approaches EMS/EMAS (resp. IMS), } \\
\text { and other environmentally oriented approaches aimed at application of EST especially with the } \\
\text { possible use of EL, LCA, etc.. }\end{array}$} \\
\hline
\end{tabular}

Table 3. Examples of management tools and methods application

\section{Case study from the enterprise}

Case study relates to a company which is engaged in manufacturing of automotive components. The company has implemented environmental management system according to ISO standards 14000. This standard of environmental 
management system helps enterprises decrease its ecological intensity, and reduce the pollution and waste. The company opted for implementation of the environmental management system according to standard ISO 14001, because it is a global company located in the United States. The implementation of environmental management system according to EMAS II relates to the countries of the European Union. Application of pro-environmental voluntary instruments at an organization as EMS takes its environmental responsibilities beyond the standards set by the legislative-sanction instruments of state policy.

The company set itself the aim to reduce its energy intensity by 30 percent by year 2018 and have achieved a 11.7 percent reduction through the end of year 2012. Other environmental goals by year 2018 are to reduce waste intensity by 20 percent, to reduce water intensity by 10 percent and to reduce greenhouse gas emissions intensity by 30 percent. The company its goals gradually the meets and everything publishes using the environmental reporting. Sustainable development also focus extends to their supply partners. It cooperates with more than 100,000 direct and indirect suppliers throughout the world and expects them to conduct their operations in an environmentally and socially sustainable manner. They use a variety of tools to assess suppliers, including background checks, self-assessment surveys, site visits and audits. Of course, companies should be deal with how to mitigate its impact on the environment, but it is also important to give priority to cooperation with other companies that are also environmentally responsible. Therefore, these companies have an advantage in the competitive struggle [7]. Pro-environmental application of voluntary instruments has become not only part of the competitive struggle among them but also company's image.

\section{Conclusion}

While most previous studies focused on an index of emissions toxicity, this study examines three areas of impacts, none of which have been explored in the literature: natural resource use, solid waste generation, and wastewater effluent. The study is also unique in that the effectiveness of standards ISO 14000 are considered in relation to environmental regulations. Our findings are summarized as follows. First, both ISO 14001 and report publication help reduce all three impacts; the former appears more effective in all areas except wastewater. Second, environmental regulations do not weaken the effect of ISO 14001. Third, assistance programs offered by local governments a voluntary approach promote facilities' adoption of ISO 14001. These findings suggest that governments can use command-and-control and voluntary approaches concurrently. The prospect of such an approach should be sustainable society development. Formalized environmental management systems are currently being implemented a worldwide. EMS, either according standards ISO 14000 or EMAS, are among the most famous and the best tools for all types of large enterprises allowing to integrate environmental aims into their activities especially. It is a voluntary proactive tool giving effect to the more integrated and more flexible measures to reduce the negative impacts of the organization and its activities on the environment.

The main goal of this paper is to show on the potential role for voluntary initiatives and environmental regulations in the transition toward more sustainable industrial systems, in light of these criteria. The application of environmental regulations being instituted in most countries and using of voluntary management tools to environmental protection may encourage proper environmental planning for future industrial development. In addition, voluntary initiatives can solve some problems that are not covered by environmental legislation and may lead to cost-effective solutions. Future research could also examine whether positive the results from implementation of environmentally oriented approaches are consistent for small and medium enterprises (SME) and across countries.

\section{Acknowledgments}

This paper was written in frame of the work on the projects VEGA 1/0990/15 „The readiness of industrial enterprises to implement the requirements of standards for quality management systems ISO 9001:2015 and environmental management systems ISO 14001:2014“"and project VEGA 1/0537/15 „Research of influence of chosen parameters of working environment on working power and productivity “.

\section{References}

[1] Dvorakova, L. \& Zborkova, J. (2014). Integration of Sustainable Development at Enterprice Level In: Procedia Engineering Vol. 24, no. 69, p. 686-695 ISSN: 1877-7058

[2] Hurt. U.; Otto. T.; Korbe. K. \& Koppel. O. (2015) New Approach to Knowledge Transfer Environment Development. Procedia Engineering, Volume 69, 2014, pp. 273-281

[3] Lee, G. B. \& Ko, M. (2012) Assessment of Environmental Impacts of the Post-Drill Cleaning Process for PCB using LCA, Annals of DAAAM for 2012 \& Proceedings of the 23rd International DAAAM Symposium, Volume 23, No.1, pp. 49-52. ISSN $2304-1382$ 
[4] Kralikova, R., Rusko, M. \& Badida, M.(2013) Six sigma method applying within environmental management, Advanced Materials Research, Vol. 739, pp. 700-705. ISSN: 10226680

[5] Micieta, V. et al. Sustainable concept for green logistics and energy efficiency in manufacturing In: DAAAM International Scientific Book 2015 : Chapter 33 P. 391-400 ISSN: 1726-9687 ISBN: 978-3-902734-05-1

[6] Petek, J., Glavic, P., Kostevsek, A. et al. (2016) Comprehensive approach to increase energy efficiency based on versatile industrial practices In: Journal of Cleaner Production Vol. 112. pp. 2813-2821 ISSN: 0959-6526

[7] Polankova, M. ; Manlig, F. \& Kralikova, R. (2015). Environmental reporting in the enterprise and related issues MM Science Journal, 2015 (October), pp. 691-695. ISSN: 18031269

[8] Paton, B.(2000) Voluntary environmental initiatives and sustainable industry.In: Business Strategy and the Environment; Vol.9 Sep/Oct 2000; 9, 5; ProQuest Central, p. 328

[9] Rusko, M.; Sablik,J.; Markova, P.; Lach, M. \& Friedrich, S. (2014) Sustainable Development, Quality Management System and Environmental Management System in Slovak Republic, 24th DAAAM. Procedia Engineering, Volume 69, 2014, pp. 486-491.

[10] UNEP (2004) Voluntary Environmental Initiatives For Sustainable Industrial Development. United Nations Publication. 55 p. ISBN 92-807-2480-0

[11] Environmental management: The ISO 14000 Family of International Standards [online]. ISO Central Secretariat. Switzerland, 2009 ISBN 978-92-67-10500-0.

Available from <http://www.iso.org/iso/theiso14000family_2009.pdf> [cit. 2016-04-14] 